\title{
Persuasion in Politics
}

\section{Citation}

Murphy, Kevin M, and Andrei Shleifer. 2004. "Persuasion in Politics." American Economic Review 94 (2) (May): 435-439. doi:10.1257/0002828041301687.

\section{Published Version}

doi:10.1257/0002828041301687

\section{Permanent link}

http://nrs.harvard.edu/urn-3:HUL.InstRepos:27867244

\section{Terms of Use}

This article was downloaded from Harvard University's DASH repository, and is made available under the terms and conditions applicable to Other Posted Material, as set forth at http:// nrs.harvard.edu/urn-3:HUL.InstRepos:dash.current.terms-of-use\#LAA

\section{Share Your Story}

The Harvard community has made this article openly available.

Please share how this access benefits you. Submit a story.

Accessibility 


\title{
NBER WORKING PAPER SERIES
}

\section{PERSUASION IN POLITICS}

\author{
Kevin Murphy \\ Andrei Shleifer \\ Working Paper 10248 \\ http://www.nber.org/papers/w10248
NATIONAL BUREAU OF ECONOMIC RESEARCH 1050 Massachusetts Avenue
Cambridge, MA 02138
January 2004

We thank Robert Bates, David Laibson, Jesse Shapiro, Kenneth Shepsle, Daniel Treisman, and Janet Yellen for helpful comments. The views expressed herein are those of the authors and not necessarily those of the National Bureau of Economic Research.

(C2004 by Kevin Murphy and Andrei Shleifer. All rights reserved. Short sections of text, not to exceed two paragraphs, may be quoted without explicit permission provided that full credit, including (C notice, is given to the source. 
Persuasion in Politics

Kevin Murphy and Andrei Shleifer

NBER Working Paper No. 10248

January 2004

JEL No. D72, D78

\section{$\underline{\text { ABSTRACT }}$}

We present a model of the creation of social networks, such as political parties, trade unions, religious coalitions, or political action committees, through discussion and mutual persuasion among their members. The key idea is that people are influenced by those inside their network, but not by those outside. Once created, networks can be "rented out" to politicians who seek votes and support for their initiatives and ideas, which may have little to do with network members' core beliefs. In this framework, political competition does not lead to convergence of party platforms to the views of the median voter. Rather, parties separate their messages and try to isolate their members to prevent personal influence from those in the opposition.

Kevin Murphy

Graduate School of Business

University of Chicago

1101 East $58^{\text {th }}$ Street

Chicago, IL 60637

and NBER

murphy@gsb.uchicago.edu

Andrei Shleifer

Department of Economics

Harvard University

M9 Littauer Center

Cambridge, MA 02138

and NBER

ashleifer@harvard.edu 
Recent research on social psychology and public opinion identifies a number of empirical regularities on how people form beliefs in the political and social spheres. First, beliefs are flexible and can be relatively easily influenced, particularly in areas where people do not have significant personal involvement (Doris Graber 1984, John Zaller 1992). Second, social influence shapes decisions: people are often persuaded by those they personally interact with (Mark Grasnovetter 1973, Robert Cialdini 1984). Such influence from friends, co-workers and other "discussants" significantly affects the decisions on whether and how to vote (Paul Beck, Russell Dalton, Steven Greene, and Robert Huckfeldt 2002). Third, in the political arena, voter awareness of specific issues is quite low, and hence susceptibility to persuasion is high (Zaller 1992).

We present a model of the creation of social networks, and of their use by politicians to obtain support, motivated by these empirical findings. These networks can be political parties, trade unions, religious coalitions, political action committees, or even listeners of Rush Limbaugh's radio show. The key idea is that people are influenced by those inside their network, but not by those outside, because those inside a network talk to and persuade each other. Networks are created by entrepreneurs using core issues that are centrally important to members, such as religious beliefs or union wages, but can then be "rented out" to politicians who seek votes as well as support for other initiatives and ideas, which might have little to do with their members' core beliefs.

\section{A Simple Model.}

We assume that there is a continuum of agents, uniformly distributed on the interval 
$[0,1]$. There is only one issue over which agents hold prior beliefs. The location $i$ of the agent determines his prior belief $x_{i}^{0}$ on the issue in question. Agents interact with those in their network, and in the process influence, as well as become influenced by, the views of others. Let $x_{i}^{*}$ denote the equilibrium beliefs of agent $\mathrm{i}$, after he has interacted with those in his network, and let $\overline{x_{i}}$ be the average equilibrium belief of those in his network, or the network's equilibrium message. Let $N_{i}$ be the size of the network that agent $\mathrm{i}$ is in, and let $f\left(N_{i}\right)$ be the influence function, defined by:

(1) $x_{i}^{*}=x_{i}^{0}+f\left(N_{i}\right)\left(\overline{x_{i}}-x_{i}^{0}\right)$

with $f(0)=0, f^{\prime}>0$, and $f^{\prime \prime}<0$.

Such personal influence may consist of exchange of information, but also appeals to friendship, emotion, or group identity (as in "Democrats don't let friends vote Republican"). The more people are in a network, the stronger is its overall influence on a person's beliefs, yet the weaker is the influence per capita. Moreover, the change in beliefs is proportional to the distance between the average equilibrium beliefs in a network and the original beliefs of its members. Networks pool the beliefs of their members closer together.

Finally, we assume that two people influence each other if and only if their equilibrium beliefs are less than $d$ apart, so $d$ is the maximum network size. That is, for two agents to be in the same network (i.e., influence each other), their equilibrium beliefs cannot be more than $d$ apart. In this model, all people inside the network influence each other equally. We only look at equilibria in which networks do not overlap. For two agents in different networks not to influence each other, their equilibrium beliefs must be at least $d$ apart, i.e., the networks must be at least $d$ apart. 
We are thus looking for the possible equilibrium structures of networks on the $[0,1]$ interval, in which two equilibrium conditions hold: a) connectedness - the size of any network cannot be larger than $d$, and b) separation - networks must be at least $d$ apart. We examine the conditions for different equilibrium configurations of networks.

\section{Grand Coalition}

Can the grand coalition, including the whole population, form in this model? It is easiest to form such a coalition with the centrist equilibrium message, so $\overline{x_{i}}=\frac{1}{2}$. Let $x_{L}$ be the equilibrium belief of the agent whose prior is zero, and $x_{H}$ be the equilibrium belief of the agent whose prior is 1 . Since we have the grand coalition, separation is not an issue. The only question is: can connectedness hold in this coalition? We can compute that

(2) $x_{L}=.5 f(1)$

(3) $x_{H}=1-.5 f(1)$

The connectedness condition holds that:

(4) $x_{H}-x_{L}=1-f(1)<d$.

How can this condition be interpreted? A higher maximum size of the network, $d$, means either that people are capable of listening to a broader range of views, or, equivalently, that the range of views in the society is smaller relative to whom people talk to. The value $f(1)$ refers to the maximum total influence in the grand coalition. Condition (4) says that if the society is sufficiently connected that people at the opposite ends of the grand coalition can still influence each other, then the grand coalition is an equilibrium. Obviously, the grand coalition is more likely to form when $d$ is high: severely segmented societies are unlikely to form such networks. 


\section{Two Equal-Sized Networks}

Can two equal sized networks, around $\frac{1}{4}$ and $\frac{3}{4}$, be an equilibrium. Let $x_{L}$ and $x_{H}$ be the lowest and highest equilibrium beliefs, respectively, of the members of the low (left) network. There is an identical in size network around $\frac{3}{4}$. In a symmetric equilibrium, the size of each network, $x_{H}-x_{L}$, must be smaller than $d$, and the distance between them, $1-2 x_{H}$, must be higher than $d$. We can compute that:

(5) $x_{L}=0+f\left(\frac{1}{2}\right)\left(\frac{1}{4}-0\right)=\left(\frac{1}{4}\right) f\left(\frac{1}{2}\right)$,

(6) $x_{H}=\frac{1}{2}+f\left(\frac{1}{2}\right)\left(\frac{1}{4}-\frac{1}{2}\right)=\left(\frac{1}{2}\right)-\left(\frac{1}{4}\right) f\left(\frac{1}{2}\right)$.

The equilibrium conditions then become:

(7) $x_{H}-x_{L}=\frac{1}{2}-\frac{1}{2} f\left(\frac{1}{2}\right)<d$, or,

(8) $1-f\left(\frac{1}{2}\right)<2 d$;

and

(9) $1-2 x_{H}=1-1+\frac{1}{2} f\left(\frac{1}{2}\right)>d$, or,

(10) $f\left(\frac{1}{2}\right)>2 d$.

When (8) and (10) both hold, two equal-sized networks form an equilibrium. For a given influence function $f$, there may exist a range of parameter values $d$ for which the grand coalition and two equal sized networks are both equilibria. These $d$ 's are high enough that the grand coalition can form, but low enough that it is possible to keep the two networks separated. Multiplicity of equilibria is pervasive: we can also have asymmetric equilibria, equilibria with small fringe networks and large mainline networks, and so on. The higher is $d$, the more likely are equilibria with large networks, but for highly polarized societies, with small $d$ 's, we can only have equilibria with many small networks. In a dynamic framework, some networks may 
become unstable and disappear, because the channels of influence among their members weaken, or because they become invaded and influenced by different opinions.

In summary, the model shows how networks of like-minded individuals can form in equilibrium. These networks are not like telephone networks, where communication channels are established technologically, and then can be filled with any messages. Rather, here the issues, and the resulting shared beliefs, bind the network together. People may start apart from each other in their views, but through communication they converge closer to each other, and further away from people with different beliefs. (Obviously, if $f^{\prime}$ is high enough, there is an equilibrium where everyone converges to identical beliefs.) Thus unions might bring members together around beliefs about their shared economic interests, religious coalitions might bring networks together around shared faith, and political action committees might bring together devotees of specific causes. Political parties have some of the same features: Republicans might keep supporters together through patriotism, opposition to abortion and support of tax cuts, while Democrats bind supporters by emphasizing civil liberties (for the elites), the right to choose, and redistribution. This model of networks shaped by shared beliefs is closely related to George Akerlof and Rachel Kranton's (2000) model of identity and Robert Putnam's (1993) idea of social capital of a community.

We described the possibility of multiple stable equilibria, with one, two, or even more networks forming. In these equilibria, people in different networks are too far apart in their beliefs to persuade each other. Such separation is essential for the leaders of the networks: if a network comes too close to others, its members might come under foreign influence, and as a consequence the ideological coherence of the network is endangered. Organizers of extremist 
networks do not want mainstream opinion to come close to their views: by infecting the beliefs of their members, such convergence can destroy the network altogether. Consistent with this prediction, organizers of extreme movements often insist on total control of their members' beliefs as well as physical separateness from the rest of the world, to prevent the dilution of beliefs by the mainstream opinion.

If networks are thought of as political parties, our results suggest both how parties form and why the Downsian prediction of convergence in their platforms to the median voter's beliefs may not be valid. In our model, if party platforms converge, members of the competing parties begin to influence each other, and the parties lose control over the beliefs and preferences of their members. It might be electorally advantageous to choose more extreme platforms, and to thus keep the members isolated from the influence of the opposition. This would be especially true if one party thinks that its coalition is sufficiently large to win the election: convergence toward the center then unambiguously reduces the chances of electoral success. There are strong incentives in this model to polarize, and to avoid the formation of the grand coalition with a tossup in the election.

\section{Networks and Political Leverage.}

Networks offer political leverage. Some of the messages that are broadcast over these networks corroborate the core beliefs of their members and reinforce network identity. Through mutual persuasion, these messages bind members of a network together. Suppose now that there is another, totally orthogonal, issue that the members of the network have no views about, because of their political apathy or "low awareness." The network provides a communication 
structure for persuading its members of a particular position with respect to this new issue. If the members' prior is very diffuse, their posterior belief becomes that of the network as a whole. The network is a cheap and efficient mechanism for sending such messages, because it leverages the persuasive capacity and credibility of its own members.

This characteristic of networks makes them valuable to politicians, who need only to persuade the leadership of the network on any of such non-core issues, and get the whole network to support their positions. A politician can persuade the leadership by endorsing the network's position on its core belief, by offering resources, or simply by persuading its leadership. Networks thus become powerful political forces--both through votes and through other forms of support--even on issues that their members do not care much about.

Two examples illustrate this principle. Conservative and religious organizations support President Bush because he promotes their beliefs. But they also support him on the war in Iraq. Now, the Republican networks would not necessarily be in favor of that war, since they have often taken isolationist positions, including most recently on international trade, the Kyoto agreement, and the U.N. endorsement of the very same war. Yet once the President has convinced the leaders of his principal networks to support the war, the persuasion channels supplied by these networks generated broad support from members who could have equally enthusiastically taken the isolationist position (and have supported such positions on other matters). Likewise, President Clinton managed to get some of the core Democratic networks, which he supported through social and other policies, to endorse NAFTA, a policy toward which their members were at best neutral.

Our analysis points to a somewhat different view of political competition. In this view, 
social entrepreneurs such as union or religious leaders are the brokers creating the networks using issues that bind members together. They can then "rent out" their networks to candidates who seek support. Voting support in an election is itself a good example of this: many voters are rather indifferent among the candidates, and can be persuaded how to vote. By receiving endorsements from network organizers, politicians get access to members who can then persuade each other to support them.

Thinking of political competition in terms of networks also points to some characteristics of a desirable communications strategy for a candidate. The best positions bind the networks that support you, and divide those of your opponent. For example, what would be the issues for presidential candidates to promote in the 2004 election? The binding issues for key Republican networks are religion, opposition to abortion, and tax cuts. Among those, the opposition to abortion is probably least attractive, because the opposing position also unites and binds many Democrats. On the other hand, some religious issues, such as the opposition to gay marriage, are tremendously attractive to the Republicans, because they both unify their core networks and divide the Democratic ones. Likewise, tax cuts are attractive as a message because they both bind the Republican networks, and divide the Democratic ones: many Democrats support the tax cut to the middle class.

For the Democratic party, it is harder to find such binding issues that also divide the opposition. A key message in the current campaign might be protectionism, of "fair trade," an issue that unifies many Democratic networks, but divides at least some of the Republicans. In a similar spirit, we would expect the Democrats to run a big "safety net for the middle class" campaign on matters such as health and education, both because it unites their networks and 
divides those of the opposition. Opposition to the war in Iraq is more problematic: it is only a good strategy if the Democrats are united this view, and Republicans are divided. And the civil liberties concerns about the Bush administration that bind the elite Democrats are poor campaign issues because they divide the Democrats' own networks.

\section{Conclusion.}

This paper has presented a simple model of formation of social networks through which people persuade and influence each other. The key feature of the model is that social entrepreneurs can organize networks around core beliefs that bind members together, and then rent out these networks to politicians seeking support. We argued that this framework is useful for thinking about efficient messages in political campaigns, including the present one.

More generally, this paper is part of a growing body of research in economics that assumes that individual beliefs on many issues are flexible, and that as a consequence people are vulnerable to persuasion and influence. Hard information is only one tool of such influence, opinions and stories of trusted authorities, firms, media, and friends are as important. This perspective has had some influence on economic research in finance (Harrison Hong, Jeffrey Kubik, and Jeremy Stein 2004), education (Michael Kremer and Andrei Sarychev 2000), social beliefs such as hatred (Edward Glaeser 2002), and media (Sendhil Mullainathan and Andrei Shleifer 2003). It may very well be broadly useful for thinking about politics. 
References

Akerlof, George, and Rachel Kranton, "Economics and Identity,” Quarterly Journal of

Economics, 2000, 115(3), pp. 715-753.

Beck, Paul, Russell Dalton, Steven Greene, and Robert Huckfeldt, “The Social Calculus of Voting: Interpersonal, Media, and Organizational Influences on Presidential Choices," American Political Science Review, 2002, 96(1), pp. 57-73.

Cialdini, Robert, Influence: The Psychology of Persuasion. New York, NY: Quill Press, 1984.

Glaeser, Edward, 2002, “The Political Economy of Hatred,” NBER Working Paper \# 9171.

Graber, Doris, Processing the News: How People Tame the Information Tide. New York, NY: Longman Press, 1984.

Grasnovetter, Mark, “The Strength of Weak Ties,” American Journal of Sociology, 1973, 78(6) pp. 1360-1380.

Hong, Harrison, Jeffrey Kubik, and Jeremey Stein, "Social Interaction and Stock Market Participation," Journal of Finance, 2004, 59(1), pp. 137-163.

Kremer, Michael, and Andrei Sarychev, "Why Do Governments Operate Schools?” Mimeo, Harvard University, 2000.

Mullainathan, Sendhil and Andrei Shleifer, 2004, “The Market for News,” Mimeo, Harvard University, 2003.

Putnam, Robert, Making Democracy Work: Civil Traditions in Modern Italy. Princeton, NJ: Princeton University Press. 1993.

Zaller, John, The Nature and Origins of Mass Opinion. Cambridge, UK: Cambridge University Press, 1992. 